(continued from page 200)

come next spring, will deal with storage of unprocessed waste, and will no doubt be optimistic too.

When the three parties under the prime minister, Mr Fälldin, began their coalition rule, they anticipated difficulty over the nuclear power issue, and they wrote into their common programme the possibility of holding an advisory referendum if they failed to agree. But the consequences of a referendum have changed in the last few weeks, since Fälldin threatened to resign if the vote went against him. So a referendum would simply be an election in another guise. In fact a general election is, according to Fälldin, a distinct possibility.

With Fälldin's position hardening, the government will have to deal with applications expected from the State Power Board early next year to load the Ringhals 3 and Forsmark 1 reactors. The Prime Minister has already refused to allow Ringhals 3 to be loaded once, saying that the State Power Board had not fulfilled the security conditions, and he has recently said that if it is loaded he will resign. March will be no less momentous a month. President Carter is then expected to enlarge on his proposal to store Sweden's (and other countries') unreprocessed spent fuel in the USA. Fälldin's coalition partners are reportedly willing to accept Carter's invitation, but Fälldin is doubtful about releasing spent fuel to storage facilities which have had their own technical troubles. Also in March the Energy Commission is to present its report on alternative energy futures to Parliament. Whether it will be able to come up with some viable transition to environmentally-benign energy production is as yet unknown. But unless it does, Fälldin's tactics seem bound to end in either a devastating loss of face for his party, or in his own resignation.
THE most recent technical tour de force of genetic engineering to receive attention in the media is the production of the human neurohormone somatostatin from a synthetic gene inserted into bacteria. It was disclosed in a rather unorthodox fashion at a recent US Senate subcommittee enquiry into the need for federal legislation to control research on recombinant DNA. The disclosure was made by Philip Handler, President of the US National Academy of Sciences, who cited the work as evidence for the potential benefits of such research.

There is no doubt that this latest achievement, which is due to a team led by Herbert Boyer of the City of Hope Medical Center in California, is an important technical step forward. Insulin genes were successfully transplanted into bacteria earlier this year, but it has so far proved impossible to get the bacteria to produce insulin from them. Boyer's team, instead of isolating and transplanting a real gene, synthesised a nucleotide sequence corresponding to the sequence of 18 amino acids that go to make up somatotropin. That gave them an 'artificial gene' which they have not only inserted into bacteria, but persuaded the bacteria to decode into somatostatin.

Boyer and his colleagues have been reluctant to disclose details of their experiments because the work is still unpublished. But it seems that the 'artificial gene' was inserted into a plasmid containing part of the bacterial lac operon-a package of bacterial genes that controls the production of the enzyme $\beta$-galactosidase. The somatostatin gene was placed in the middle of the $\beta$-galactosidase gene, where the two genes would be transcribed together under the control of the lac promotor gene. The resultant RNA was apparently translated into a hybrid protein from

which the somatostatin could be chemically cut off.

How important, in general, is this technique? And specifically, how important is the artificial production of somatostatin? The main point

\section{Proteins from synthetic genes}

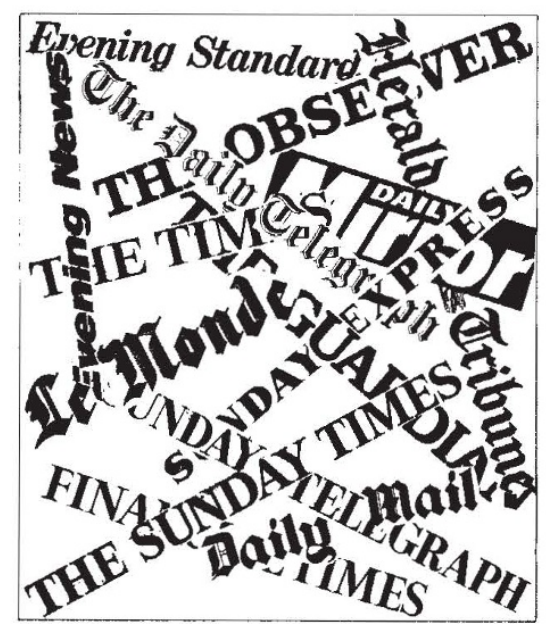

BACKGROUNDER

about the technique is that it shows that it is possible to induce bacteria to make animal gene products. The demonstration that this can be done with synthetic genes may have two important consequences. First, there is mounting evidence that the genes of higher animals are different from those of bacteria in that they contain regions of DNA that do not code for the final protein. Since it is unlikely that a bacterium would be equipped to cope with such discontinuous genes, it is important to know that a simple coding sequence can be used instead of an actual gene. Second, there are now many cases in which what is needed for medical purposes is not the natural protein but a specific analogue of it. If bacteria can be made to produce the original from an artificial gene, then they can presumably also work on an artificial gene coding for an analogue.

There are also two important limitations on the technique, however. First, it is only practical to make synthetic genes for relatively small molecules, and small molecules are not very difficult to synthesise by traditional means. Whether genetic engineering will eventually prove the cheaper way it is hard to gauge. Second, the particular method Boyer's team used to clip the somatostatin out of the hybrid protein is not generally applicable. It depends on the fact that the bacterial protein contains a specific chemical group that is not present in somatostatin. However, it is present in most proteins.

Somatostatin itself is unlikely to be very widely used for clinical purposes. It inhibits the release of the hormones glucagon, thyrotrophin, prolactin, gastrin and insulin. Because of its inhibition of hormones that act against insulin, it has been clinically tried in cases of extreme insulin-resistant diabetes (less than $5 \%$ of diabetics). But because of its effects on other hormones, and the fact that it inhibits the aggregation of platelets and may thus predispose to haemorrhage, it is most unlikely to find more widespread application. Attempts have been made to find analogues with more specific action, but they have so far failed and it may be that all the diverse actions of the neurohormone depend on the same chemical feature.

At this stage, therefore, the remarkable achievement of Boyer and his collaborators remains an advance in principle rather than in practice. 